\title{
Gluten-Free Ancient Whole Grain Buckwheat Snacks
}

\author{
Talwinder S Kahlon ${ }^{1 *}$, Roberto J Avena-Bustillos ${ }^{1}$ and Mei-Chen M Chiu ${ }^{1}$ \\ ${ }^{1}$ Western Regional Research Center, USA
}

Submission: March 20, 2018; Published: April 19, 2018

*Corresponding author: Talwinder S Kahlon,Western Regional Research Center, USDA-ARS, 800 Buchanan St. Albany, CA 94710, Tel: 510-559-5665; Fax: 510-559-5945; Email: Talwinder.Kahlon@ars.usda.gov

\begin{abstract}
The Buckwheat, Buckwheat-Turmeric, Buckwheat-Cayenne Pepper and Buckwheat-Ginger snacks were evaluated. Turmeric, cayennepepper and ginger have been reported to have health promoting potential as wound healing, increasing blood flow and preventing joint pain. All the snacks contained $88-92 \%$ buckwheat. Snack dough was prepared using $120 \mathrm{~mL}$ water with $100 \mathrm{~g}$ dry ingredients. About $20 \mathrm{~g}$ of snack dough was placed on the center of preheated KrumKake Express baker and cooked for 2.5 minutes. Seventy one in-house volunteers judged BuckwheatGinger snacks significantly higher in Odor/Aroma than Buckwheat-Cayenne Pepper snacks. Color/Appearance, Taste/Flavor, Texture/Mouthfeel and Acceptance were judged to be similar in four kinds of Buckwheat ancient whole grain gluten-free snacks tested. Water activity of all the snacks tested ranged from 0.21-0.32 suggesting that these snacks were crispy and would have good anti-microbial stability. These snacks were quite filling due to their high porosity (0.68-0.75) and 3 to 4 -fold expansion. Acceptance of snacks tested was statistically similar and ranged from $70-84 \%$. This acceptance would be considered quite desirable. These snacks contained only 3-4 ingredients and could be made in any house kitchen or commercial production. These healthy nutritious snacks offer choice for all including vegetarians and individuals sensitive to gluten.
\end{abstract}

Keywords: Buckwheat; Gluten-free; Turmeric; Cayenne pepper; Ginger; Nutrition; Dietary; Gluten immunity

Abbreviations: BW: Buckwheat; $\rho t$ : True Density; $\rho$ : Bulk Density; TDF: Total Dietary Fiber; DM: Dry Matter

\section{Introduction}

Snacks play a significant role in family as well as public events. There are 69 million US adults currently between the ages of 18-34 called Millennials. The snacks are preferred in place of meals by $35 \%$ of the Millennials $[1,2]$. The snacks are now expected to be healthful, flavorful, and portable [1]. For children, snacks are extremely essential in school and in after school programs. Serving healthy snacks is important in providing good nutrition, supporting lifelong healthy eating habits, and would help in preventing costly and potentiallydisabling diseases, such as heart disease, cancer, diabetes, high blood pressure, and obesity. Nutrition Policy and Promotion; Dietary Guidelines for Americans [3] recommends that, at least $1 / 2$ of all the grains eaten should be whole grains. Average intakes of whole grains are far below recommended levels across all age-sex groups, and average intakes of refined grains are well above recommended limits for most age-sex groups. The Whole Grain Council [4] has documented that eating whole grains instead of refined grains lowers the risk of many chronic diseases. Helnaes et al. [5] reported that higher intake of whole grain rye and oats and not that of wheat was related to lower risk of myocardial infarction in men and women. Wheat is the main grain of many snack products, however there is increasing evidence of hyper-sensitivity to gluten in the celiac patients. Hypersensitivity to gluten results in eroding of the lining of small intestines. It results in delayed growth and many serious health problems. Healthy intestinal lining is needed to absorb the needed nutrients. Food and Drug Administration [6] defines "gluten-free" with less than 20 parts per million, gluten. This is the level that can be validly tested and also can be tolerated by most gluten sensitive individual. Hypersensitivity to gluten has been increasing worldwide. Some of the potential reasons could be use of microbial transaminase enzyme as animal protein glue to produce meat patties from meat scraps. Transamination of gluten could make it hypersensitive. Another reason could be that pollution and toxic environment has altered gut microbiome resulting in loss of gluten immunity. If one family member is gluten sensitive, the whole family needs to consume glutenfree foods. Snacks made of gluten-free whole grains would be desirable. Since most individuals and especially children do not meet the recommended intake of whole grains. The objective of this study was to develop tasty, health promoting, whole grain, gluten-free snacks. Snacks available in US are essentially unhealthy and contain high fat, high salt and high simple sugars [2]. Consumers need to be educated to desire healthy home cooking or health promoting commercially produced foods and snacks. There is a need to develop glutenfree whole grain nutritious tasty snacks. Such snacks could 
include health promoting spices as well. These snacks would be high in dietary fiber, low in salt, fat and calories and could be prepared in any home and/or by commercial food companies.

\section{Buckwheat}

Buckwheat (Fagopyrum esculentum) is a gluten-free pseudocereal. Buckwheat (BW) grain is a highly nutritional grain that has been shown to provide a wide range of beneficial effects. BW contains phytonutrients that have been shown to have plasma cholesterol lowering, neuroprotection, anticancer, anti-inflammatory, antidiabetic effects, and improvement of hypertension condition [7].

\section{Ginger}

Ginger (Zingiber officinale), turmeric (Curcuma longa) and cayenne pepper (Capsicum annuum 'Cayenne') are common spices in various cuisines and have been associated with various health benefits. Thomson et al. [8] reported that ginger could be used as a cholesterol-lowering, antithrombotic and anti-inflammatory agent.

\section{Turmeric}

Turmeric (Curcuma longa) has been shown to exhibit antiinflammatory, antimicrobial, antioxidant, and anti-neoplastic properties. There is evidence that turmeric products and supplements, both oral and topical, may provide therapeutic benefits for skin health [9]. Addition of $4 \%$ ginger or turmeric prevented the effect of hypertension inducing drug in rats [10]

\section{Cayenne Pepper}

Kobayashi et al. [11] observed that cayenne pepper activates heat loss as well heat production. Inoue et al. [12] reported that hot pepper intake enhanced the energy expenditure and fat burning in humans, particularly those with high body mass index. Han \& Isoda [13] reported that capsaicin found in hot chili pepper increases energy metabolism in human epithelial cells through the activation of glycolytic enzymes.

In the study reported herein, seventy-one in house volunteers evaluated four kinds of snacks containing glutenfree ancient whole grain buckwheat (BW), BW-Turmeric, BWCayenne Pepper and BW-Ginger.

\section{Material and Methods}

Whole grain buckwheat (hulls removed), turmeric powder, ginger powder and ground cayenne pepper were purchased from local food stores. Buckwheat grains were milled to fine flour using Blendtec Model 91 Kitchen Mill (Blendtec Orem, UT 84058). Buckwheat flour was analyzed for nitrogen, using AOAC method 990.03 [14] by Leco FP628 analyzer (Leco Corporation, St Joseph, MI); total dietary fiber, using AOAC method 985.29 [14], crude fat with petroleum ether and an accelerated solvent extractor (ASE 350, Dionex Corp.); ash, using AOAC method 942.05 [15]; and moisture, using AOAC method 935.29 [15].
Table 1: Composition of Gluten-Free Ancient Whole Grain Buckwheat dry matter basis, $\%$

\begin{tabular}{|c|c|c|c|c|c|c|}
\hline $\begin{array}{c}\text { Ingred- } \\
\text { ients }\end{array}$ & Protein & Fat & Ash & $\begin{array}{c}\text { Carbohy- } \\
\text { drates }\end{array}$ & TDF & DM \\
\hline Buckwheat & 14.2 & 3.49 & 2.86 & 79.45 & 11.25 & 88.85 \\
\hline
\end{tabular}

Nitrogen to protein factors used was 6.25. Total Dietary Fiber TDF; Dry matter, DM. Carbohydrate $=[100-($ Protein + Fat + Ash $)]$ Samples were analyzed in triplicates.

Table 2: Dough Composition of Gluten-Free Ancient Whole Grain Buckwheat Snacks, as is basis, \%

\begin{tabular}{|c|c|c|c|c|c|c|c|}
\hline Snacks & Flour & Oil & Salt & $\begin{array}{c}\text { Tur- } \\
\text { meric }\end{array}$ & Pepper & Ginger & Water \\
\hline $\begin{array}{c}\text { Buckw- } \\
\text { heat } \\
\text { (BW) }\end{array}$ & 92 & 6 & 2 & --- & --- & --- & $120 \mathrm{ml}$ \\
\hline $\begin{array}{c}\text { BW- } \\
\text { Turmeric }\end{array}$ & 88 & 6 & 2 & 4 & --- & --- & $120 \mathrm{ml}$ \\
\hline $\begin{array}{c}\text { BW- } \\
\text { Pepper }\end{array}$ & 91.5 & 6 & 2 & --- & 0.5 & --- & $120 \mathrm{ml}$ \\
\hline $\begin{array}{c}\text { BW- } \\
\text { Ginger }\end{array}$ & 88 & 6 & 2 & --- & --- & 4 & $120 \mathrm{ml}$ \\
\hline
\end{tabular}

The final levels of ingredients in the snacks tested were decided from the triplicate approved consensus of laboratory personnel.

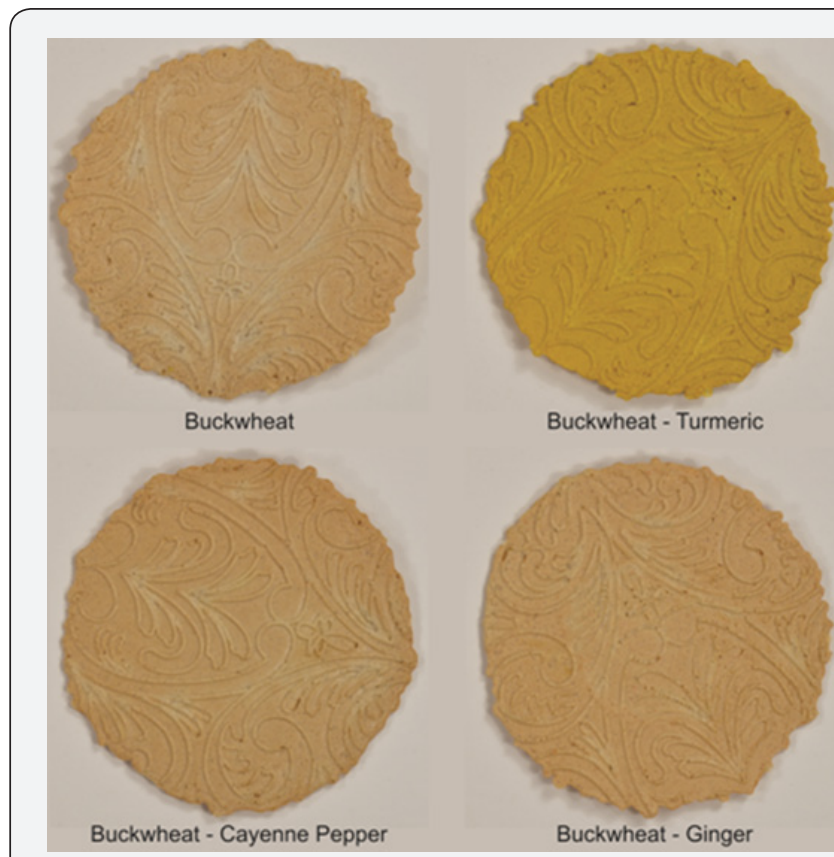

Figure 1: Shows four kinds of Gluten-Free Ancient Whole Grain Buckwheat Cooked Snacks.

Composition of Buckwheat flour is given in Table 1. Dough composition of buckwheat ancient whole grain gluten-free snacks is given in Table 2. Buckwheat with several levels of oil, and salt were evaluated to arrive at the desired formulation. Four to six levels of turmeric, cayenne pepper and ginger were tested in triplicate. The final levels of these ingredients of the snacks tested were decided from the consensus of laboratory personnel. Snacks dough was prepared by adding $120 \mathrm{~mL}$ water to $100 \mathrm{~g}$ of dry ingredients. Dough was set at 
room temperature for 30 minutes. Snacks were cooked in a 1050Watt, Chef's Choice KrumKake Express 839 (EdgeCraft Corporation Avondale, PA 19311 USA). KrumKake Express with heat control dial settings 1-6 was heated at setting 4 till green ready light turned on. Baking temperature ranged from 185-208 ${ }^{\circ} \mathrm{C}$ as measured by Anritsu Meter AP-710 (Anritsu meter Co., Tokyo, Japan). Cooking surface was lightly sprayed with Pam, non-stick cooking spray (ConAgra Foods, Omaha, NE) and 20g snack dough was placed on the center of heated KrumKake baker and cooked for 2.5 minutes. Figure 1 shows four kinds of buckwheat ancient whole grain gluten-free cooked snacks. Cooked snacks were cooled to room temperature then vacuum heat sealed in plastic bags by Food Saver 2200 Series (Foodsaver.com).

\section{Sensory evaluation of snacks}

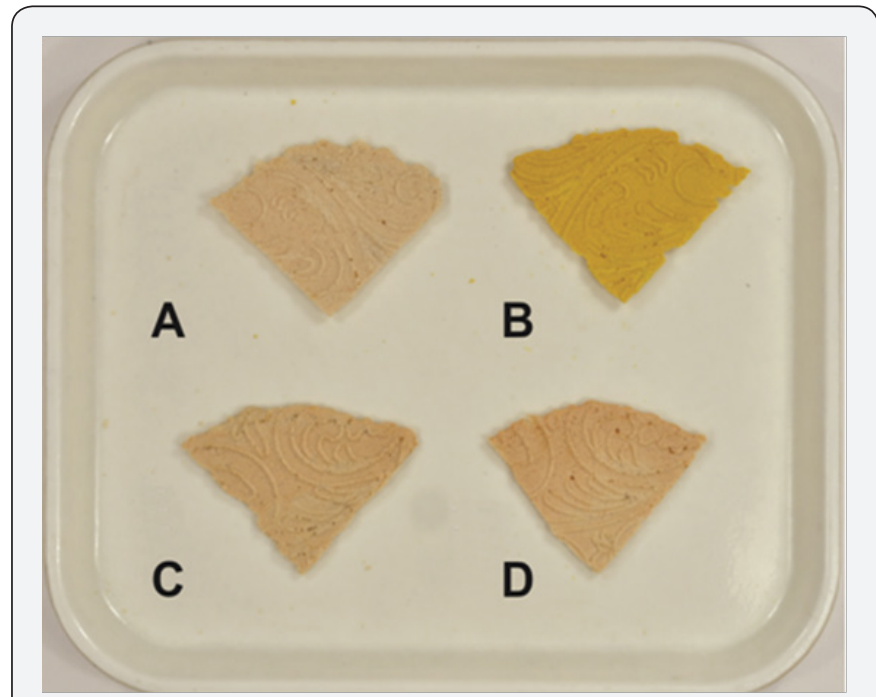

Figure 2: Shows Gluten-Free Ancient Whole Grain Buckwheat Snacks as Offered for Sensory Evaluation to the Tasters. A) Buckwheat; B) Buckwheat-Turmeric; C) Buckwheat-Cayenne Pepper; D) Buckwheat-Ginger.

Seventy-one in-house volunteers tasted the snacks in the sensory evaluation individual booths under white light for Results and Discussion
Color/Appearance, Odor/Aroma, Taste/Flavor, Texture/Mouthfeel and Acceptance. The sensory parameters were evaluated on a scale of 1-5 (Like very much $=5$, like slightly $=4$, neutral $=3$, dislike slightly $=2$ and dislike very much $=1$ ); Acceptance was evaluated on a scale of 1-2 (Acceptable $=2$ and unacceptable $=$ 1). Tasters were instructed to evaluate each snack individually and not for relative rating. Vacuum packed prepared snacks were opened and cut into four pieces with a pizza cutter. All four snacks were placed in a plate, appropriately labeled and offered for sensory evaluation. Figure 2 shows four kinds of buckwheat ancient whole grain gluten-free snacks as offered to the tasters in the sensory evaluation room.

Water activity: Water activity (Aw) of whole grain glutenfree buckwheat snacks was measured at $25.01 \pm 0.02{ }^{\circ} \mathrm{C}$ in triplicate using an AquaLab 4TE dew point water activity meter (Decagon Devices, Inc., Pullman, WA).

Density: The bulk density $(\rho b)$ of buckwheat snacks was measured by Ottawa Sand volume displacement by $10 \mathrm{~g}$ of sample in triplicate after 15-5-5 minutes shaking in a jar of 202 cc volume. True density ( $\rho t)$ was determined five times using gas displacement pycnometer AccuPyc II 1340 (Micromeritics Instrument Co., Norcross, GA 30093) at $21.4 \pm 0.4{ }^{\circ} \mathrm{C}$. Samples of each snack were dried in triplicate at room temperature for $15 \mathrm{~h}$ at $0 \%$ relative humidity in a vacuum desiccator with anhydrous calcium sulfate (W. A. Hammond Drierite, Xenia, $\mathrm{OH})$. After drying, small pieces of samples were compressed into a density measuring cylinder of the pycnometer and five true density measurements were recorded.

\section{Statistical analysis}

Sensory evaluation data scale (1-5) and acceptability (12) for all 71 individual tasters were analyzed with Minitab software (version 14.12.0, Minitab inc., State College, PA) using basic statistics for mean and SEM and one-way analysis of variance and Tuckey's multiple comparison tests with $(\mathrm{p} \leq 0.05)$ was considered the criterion of significance.

Table 3: Results of Taste Panel of Gluten-Free Ancient Whole Grain Buckwheat Snacks.

\begin{tabular}{|c|c|c|c|c|c|}
\hline Snacks & Color Appearance & Odor Aroma & Taste Flavor & Texture Mouth Feel & Acceptance \\
\hline Buckwheat (BW) & $3.94 \pm 0.10^{\mathrm{a}}$ & $3.66 \pm 0.09^{\mathrm{ab}}$ & $3.51 \pm 0.12^{\mathrm{a}}$ & $3.92 \pm 0.12^{\mathrm{a}}$ & $1.85 \pm 0.04^{\mathrm{a}}$ \\
\hline BW-Turmeric & $3.82 \pm 0.12^{\mathrm{a}}$ & $3.56 \pm 0.11^{\mathrm{ab}}$ & $3.48 \pm 0.13^{\mathrm{a}}$ & $3.92 \pm 0.12^{\mathrm{a}}$ & $1.80 \pm 0.05^{\mathrm{a}}$ \\
\hline BW-Pepper & $4.14 \pm 0.09^{\mathrm{a}}$ & $3.45 \pm 0.09^{\mathrm{b}}$ & $3.28 \pm 0.14^{\mathrm{a}}$ & $3.78 \pm 0.13^{\mathrm{a}}$ & $1.73 \pm 0.05^{\mathrm{a}}$ \\
\hline BW-Ginger & $4.11 \pm 0.09^{\mathrm{a}}$ & $3.82 \pm 0.09^{\mathrm{a}}$ & $3.24 \pm 0.14^{\mathrm{a}}$ & $3.92 \pm 0.12^{\mathrm{a}}$ & $1.70 \pm 0.05^{\mathrm{a}}$ \\
\hline
\end{tabular}

aValues (mean \pm SEM) within columns with different letters differ significantly ( $P \leq 0.05), N=71$.

${ }^{b}$ Sensory evaluation parameters were on a scale of $1-5$ (Like very much $=5$, like slightly $=4$, neutral $=3$, dislike slightly $=2$ and dislike very much = 1); Acceptance was on scale of 1-2 (Acceptable $=2$ and unacceptable $=1)$.

Results of the taste panel evaluation of buckwheat ancient whole grain gluten-free snacks are shown in Table 3. Odor/Aroma of the buckwheat-ginger snacks was judged significantly $(\mathrm{p} \leq 0.05)$ higher than that for buckwheatcayenne pepper snacks $(\mathrm{n}=71)$. Tasters preferred aroma of zingerone (4-(4-hyroxy-3-methoxyphenyl)-2-butanone) a bioactive compound of dry cooked ginger. Zingerone has been associated with anti-inflammatory, antioxidant and many other pharmacological properties [16]. Color/Appearance, Taste/Flavor, Texture/Mouth feel and Acceptance for all the 
four kinds of snacks tested were similar. Kahlon et al. [17,18] calculated Desirability Index as percent of tasters judged [like very much + like slightly $+1 / 2$ (neutral)]. Desirability Index for buckwheat whole grain gluten-free snacks was: Buckwheat (BW), BW-Turmeric, BW-Cayenne Pepper and BW-Ginger for Color/Appearance $83 \%, 77 \%, 89 \%$ and $90 \%$; Odor/Aroma $76 \%$, $70 \%, 69 \%$ and $83 \%$; Taste/Flavor $69 \%, 68 \%, 61 \%$ and $60 \%$; Texture/Mouth feel $82 \%, 82 \%, 74 \%$ and $82 \%$; respectively.

Acceptance of Buckwheat whole grain gluten-free snacks is shown in Figure 3. Acceptance of buckwheat snacks tested was Buckwheat 84.5\%, BW-Turmeric 80.3\%, BW-Cayenne Pepper 73.2\%, and BW-Ginger 70\%. These acceptance values for the four kinds of BW snacks tested ranged from $70-85 \%$ are quite desirable and statistical similar. This is the first report containing 88-92\% ancient whole grain gluten-free buckwheat snacks.

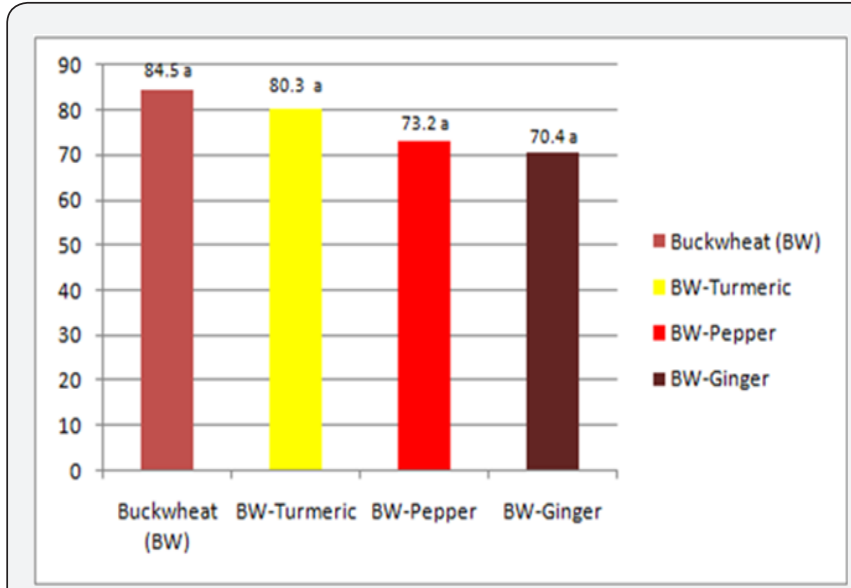

Figure 3: Acceptance of Buckwheat (BW), BW-Turmeric, BWCayenne Pepper and BW-Ginger Snacks ( $n=71)$. No significant differences in acceptance of four kinds of snacks tested.

Table 4: Water Activity (Aw), True Density ( $\rho t)$, Bulk Density $(\rho b)$ and Expansion of Gluten-Free Ancient Whole Grain Buckwheat Snacks

\begin{tabular}{|c|c|c|c|c|}
\hline Snacks & Aw & $\rho t$ & $\rho \mathbf{b}$ & Expansion $(t \rho / b \rho)$ \\
\hline Buckwheat (BW) & $0.315 \pm 0.001 \mathrm{a}$ & $1.272 \pm 0.002 \mathrm{c}$ & $0.409 \pm 0.003 a$ & $3.108 \pm 0.005 b$ \\
\hline BW-Turmeric & $0.216 \pm 0.003 b$ & $1.406 \pm 0.002 \mathrm{a}$ & $0.390 \pm 0.001 \mathrm{~b}$ & $3.601 \pm 0.004 a$ \\
\hline BW-Pepper & $0.318 \pm 0.002 \mathrm{a}$ & $1.347 \pm 0.001 b$ & $0.405 \pm 0.003 a$ & $3.328 \pm 0.003 b$ \\
\hline BW-Ginger & $0.212 \pm 0.005 b$ & $1.338 \pm 0.001 \mathrm{~b}$ & $0.338 \pm 0.003 c$ & $3.960 \pm 0.003 a$ \\
\hline
\end{tabular}

Values within columns with different letters differ significantly $(P \leq 0.05)$.

${ }^{b}$ Water activity $(\mathrm{Aw})$ was measured at $25.01 \pm 0.02{ }^{\circ} \mathrm{C}$ by triplicate using an AquaLab 4 TE dew point water activity meter (Decagon Devices, Inc., Pullman, WA).

cTrue density ( $\rho t)$ was determined, five times, using an AccuPyc II 1340 gas displacement pycnometer (Micromeritics Instrument Co., Norcross, GA) at $21.4 \pm 0.4{ }^{\circ} \mathrm{C}$. The bulk density $(\rho \mathrm{b})$ of each sample was measured by Ottawa Sand volume displacement by $10 \mathrm{~g}$ sample in triplicate after 15-5-5 minutes shaking in a jar of 202cc volume.

Water activity (Aw), true density ( $\rho \mathrm{t})$, bulk density $(\rho \mathrm{b})$ and expansion $(\rho t / \rho b)$ of buckwheat whole grain gluten-free snacks is shown in (Table 4). Water activity (Aw) of BW-Turmeric, and BW-Ginger, snacks was significantly $(p \leq 0.05)$ lower than that for BW and BW-Cayenne Pepper snacks. Data suggest that BWTurmeric and BW-Ginger snacks were crispier than BW and BW-Cayenne pepper snacks. Katz and Labuza [19] reported that snacks with Aw of 0.21-0.27 are typically very crispy. Adams and Moss [20]; Dueik et al. [21] observed that carrot snacks with Aw of 0.44 as crispy with desired antimicrobial stability. The four kinds of BW whole grain gluten-free snacks tested herein with Aw 0.21-0.32 were crispy and with high anti-microbial stability.

True density $(\rho \mathrm{t})$ values for BW-Turmeric snacks were significantly higher than other snacks tested. The $\rho$ t values for BW-Cayenne Pepper and BW-Ginger were significantly higher than BW snacks. Bulk density ( $\rho$ b) values for BW-Ginger snacks were significantly lower than other snacks tested. The $\rho b$ for BW-Turmeric snacks were lower than BW and BW-Cayenne pepper snacks. Expansion $(\mathrm{t} \rho / \mathrm{b} \rho)$ for BW-Turmeric and BWGinger was similar 3.6-3.9 and significantly higher than BW and BW-Cayenne Pepper snacks (3.1-3.3). Data suggest that higher expansion of BW-Turmeric and BW-Ginger snacks resulted in crispier chips with lower Aw. Expansion (fluffiness) of all the BW snacks tested was 3-4 times suggesting that these

snacks could result in lower caloric consumption and would give desirable fluffier presentation in commercial packaging.

\section{Conclusion}

Four kinds of ancient whole grain gluten-free buckwheat snacks were sensory evaluated by seventy-one tasters. Acceptance of these 88-92\% buckwheat containing snacks was Buckwheat 84.5\%, BW-Turmeric 80.3\%, BW-Cayenne Pepper $73.2 \%$, and BW-Ginger $70 \%$. Buckwheat is highly nutritious ancient grain. Turmeric, ginger and cayenne pepper are common spices with many reported health benefits. Water activity of the snacks tested (0.21-0.32) suggests that these snacks were crispy with good anti-microbial stability. Expansion value of 3-4 suggests that these snacks would be quite filling and offer good package presentation. These snacks could be made in any house hold or commercial production. These ancient whole grain gluten-free buckwheat snacks offer healthy choice to all and option for vegetarians and those sensitive to gluten.

\section{Acknowledgement}

Authors sincerely thank Delilah Wood for taking photographs of Figure $1 \& 2$.

\section{References}

1. GBD (2016) Mortality and Causes of Death Collaborators. Global regional and national life expectancy, all-cause mortality, and cause- 
specific mortality for 249 causes of death, 1980-2015: a systematic analysis for the Global Burden of Disease Study 2015. The Lancet 388(10053): 1459-544.

2. WHO (2014) Obesity and overweight, Fact sheet No 311.

3. Ng M, Fleming T, Robinson M, Thomson B, Graetz N, et al. (2014) Global, regional, and national prevalenceof overweight and obesity in children and adults during 1980-2013:a systematic analysis for the Global Burden of Disease Study 2013. The Lancet 384(9945): 766-781.

4. Flegal KM, Kit BK, Orpana H, Graubard BI (2013) Association of allcause mortality with overweight and obesity using standard body mass index categories: a systematic review and meta-analysis. JAMA 309(1): 71-82.

5. Carmienke S, Freitag MH, Pischon T, Schlattmann P, Fankhaenel T, et al. (2013) General and Abdominal adiposity parameters and their combination in relation to mortality: a systematic review and metaregression analysis. Eur J Clin Nutr 67(6): 573-585.

6. Yusuf S, Hawken S, Ounpuu S, Bautista L, Franzosi MG, et al. (2005) Obesity and the risk of myocardial infarction in 27,000 participants from 52 countries: a case-control study. The Lancet 366(9497): 16401649.

7. Lloyd-Jones DM, Hong J, Labarthe D, Mozaffarian D, Appel LJ, et al. (2010) Defining and Setting National Goals for Cardiovascular Health Promotion and Disease Reduction: The American Heart Association's strategic impact Goal through 2020 and beyond. Circulation 121(4): 586-613.

8. Fernández-Alvira JM, Fuster V, Pocock S, Sanz J, Fernández friera L, et al. (2017) Predicting Subclinical Atherosclerosis in Low-Risk Individuals. Ideal Cardiovascular Health Score and Fuster- BEWAT Score. J Am Coll Cardiol 70(20): 2463-2473.

9. Egeland GM, Igland J, Vollset SE, Sulo G, Eide GE, et al. (2016) High population attributable fractions of myocardial infarction associated with waist-hip ratio. Obesity 24(5): 1162-1169.

10. Martín-Castellanos A, Cabañas-Armesilla MD, Barca-Durán FJ, MartínCastellanos P, Gómez- Barrado JJ (2017) Obesity and risk of Myocardial Infarction in a Sample of European Males. Waist To-Hip-Ratio Presents Information Bias of the Real Risk of Abdominal Obesity. Nutr Hosp 34(1): 88-95

11. Romero-Corral A, Somers VK, Sierra-Johnson J, Korenfield Y, Boarin S, et al. (2010) Normal weight obesity: a risk factor for cardiometabolic

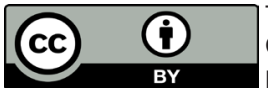

This work is licensed under Creative Commons Attribution 4.0 License

DOI: 10.19080/NFSIJ.2018.06.555687 dysregulation and cardiovascular mortality. Eur Heart J 31(6): 737746

12. Joseph P, Yusuf S, Lee SF, Ibrahim Q, Teo K, et al. (2018) Prognostic validation of a non- laboratory and a laboratory based cardiovascular disease risk score in multiple regions of the world. Heart 104(7): 581587.

13. Carter JEL (2002) The Heath-Carter Anthropometric Somatotype Instruction Manual. Department of Exercise and Nutritional Sciencies. San Diego State University: San Diego CA, USA.

14. Zeng Q, Dong SY, Sun XN, Xie J, Cui Y (2012) Percent body fat is a better predictor of cardiovascular risk factors than body mass index. Braz J Med Biol Res 45(7): 591-600.

15. Williams SR, Jones E, Bell W, Davies B, Bourne MW (1997) Body habitus and coronary heart disease in men. A review with reference to methods of body habitus assessment. Eur Heart J 18(3): 376-393.

16. Martín-Castellanos A, Cabañas MD, Martín P, Barca FJ. The body composition in myocardial infarction males. Novel findings in both the association and relationship between anthropometric indicators of risk. JONNPR 2(9): 388-398.

17. Martín-Castellanos A (2014) Anthropometric profile, body composition and somatotype study in patients with Acute Coronary Syndrome of the Health Area of Caceres. PhD Thesis, Complutense University, Madrid, Spain.

18. Brown JC, Harhay MO, Harhay MN (2017) Anthropometricallypredicted visceral adipose tissue and mortality among men and women in the third national health and nutrition examination survey (NHANES III). Am J Hum Biol 29(1)

19. Yeboach J, Blaha MJ, Michos ED, Qureshi W, Miedema M, et al. (2017) Adult Height, Prevalent Coronary Artery Calcium Score, and Incident Cardiovascular Disease Outcomes in a Multiethnic Cohort. Am Epidemiol 186(8): 935-943.

20. Nüesch E, Dale C, Palmer TM, White J, Keating BJ, et al. (2016) Adult height, coronary heart disease and stroke: a multi-locus Mendelian randomization meta-analysis. Int J Epidemiol 45(6): 1927-1937.

21. Lassale C, Tzoulaki I, Moons KGM, Sweeting M, Boer J, et al. (2018) Separate and combined associations of obesity and metabolic health with coronary heart disease: a pan-European case-cohort analysis. Eur Heart J 39(5): 397-406.

\section{Your next submission with Juniper Publishers will reach you the below assets}

- Quality Editorial service

- Swift Peer Review

- Reprints availability

- E-prints Service

- Manuscript Podcast for convenient understanding

- Global attainment for your research

- Manuscript accessibility in different formats

( Pdf, E-pub, Full Text, Audio)

- Unceasing customer service

Track the below URL for one-step submission

https://juniperpublishers.com/online-submission.php 